\title{
OPTIMALISASI PENGGUNAAN GOOGLE CLASSROOM SEBAGAI MEDIA E-LEARNING BAGI MAHASISWA KEDOKTERAN HEWAN UNIVERSITAS NUSA CENDANA
}

\author{
Dede Rival Novian \\ Fakultas Kedokteran Hewan Universitas Nusa Cendana \\ e-mail: dede.rival.novian@gmail.com
}

\begin{abstract}
Abstrak
Program Pengabdian Kepada Masyarakat yang dilakukan bertujuan untuk melatih mahasiswa kedokteran hewan Universitas Nusa Cendana menggunakan media $e$ learning Google Classroom. Dengan adanya pelatihan ini, mahasiswa dapat mengoptimalkan penggunakan Google Classroom dalam proses pembelajaran. Pelaksanaan pengabdian ini terdiri dari tiga tahap, yaitu: persiapan, pelaksanaan dan evaluasi. Tahap persiapan dilakukan untuk menggali masalah yang berkaitan dengan potensi pembelajaran e-learning. Pada tahap ini dilakukan penyampaian materi $e$ learning dan pelatihan cara mengakses dan menggunakaan Google Classroom. Tahap evaluasi dilakukan untuk mengetahui kendala selama pelatihan. Dengan adanya kegiatan ini mengakibatkan bertambahnya pengetahuan mahasiswa Kedokteran Hewan di Universitas Nusa Cendana tentang pembelajaran e-learning dan terampil dalam menggunakan Google Classroom sebagai media pembelajaran online yang interaktif dan menyenangkan dalam proses kegiatan belajar mengajar dan adanya produk e-learning yaitu Google Classroom sebagai media pembelajaran online yang mudah digunakan.
\end{abstract}

Kata Kunci: E-learning, Google Classroom, Optimalisasi pembelajaran

\section{A. Pendahuluan}

E-learning dapat didefinisikan sebagai proses pembelajaran digital melalui .jaringan internet (Jethro, et al. 2012). E-learning adalah pembelajaran yang menggunakan teknologi komputer, sehingga dapat di akses dari jarak jauh atau di dalam kelas melalui tatap muka (pembelajaran dengan bantuan komputer). $E$ learning merupakan pembelajaran yang fleksibel, individual, mandiri, berbasis teknologi, dan pembelajaran kolaboratif yang dapat meningkatkan pengetahuan dan kinerja peserta didik. Teknologi e-learning membuat peserta didik dapat mengontrol konten pembelajaran, kecepatan belajar, waktu belajar, dan memungkinkan peserta didik untuk menyesuaikan gaya belajar mereka (Arkorful, 2014). 
Inovasi dalam teknologi e-learning mengarah pada revolusi dalam pendidikan, sehingga memungkinkan pembelajaran menjadi bersifat individual (pembelajaran adaptif), meningkatkan interaksi peserta didik dengan orang lain (pembelajaran kolaboratif), dan mengubah peran pendidik. Integrasi e-learning ke dalam pendidikan dapat mengkatalisasi pergeseran menuju penerapan teori pembelajaran orang dewasa, di mana pendidik tidak akan lagi berfungsi terutama sebagai distributor semua konten, tetapi akan menjadi lebih terlibat sebagai fasilitator pembelajaran dan penilai kompetensi.

Teknologi e-learning menawarkan paradigma baru kepada pendidik, berdasarkan teori pembelajaran orang dewasa, proses belajar harus menggunakan pengalaman belajar pada masa lalu. Dengan menerapkan pembelajaran secara praktis dapat menghasilkan pengalaman belajar yang lebih efektif dan efisien, serta dapat meningkatkan partisipasi aktif dari pelajar (Algahtani, 2011).

Belajar adalah pengalaman yang sangat pribadi, kita belajar karena kita ingin belajar. Dengan demikian, penggunaan e-learning dapat membuat peserta didik menjadi aktif. E-learning yang dirancang dengan baik dapat memotivasi pelajar untuk menjadi lebih aktif dalam menggunakan konten pembelajaran sehingga proses pembelajaran menjadi lebih interaktif. Pembelajaran interaktif menggeser fokus dari model pasif yang berpusat pada guru menjadi model yang aktif dan berpusat pada peserta didik. Pembelajaran Interaktif membuat minat pelajar sangat tinggi untuk mempelajari konten pembelajaran Al-adwan, dan Smedly, 2012).

Salah satu metode e-learning yang mudah digunakan adalah Google Classroom yang dapat menyediakan kelas online, sehingga memudahkan bagi mahasiswa untuk mengakses konten pembelajaran dimana saja (Hakim, 2016). Selain itu, penggunakan Google Classroom dapat menghemat penggunaan kertas dan juga membuat pembelajaran lebih interaktif sehingga minat mahasiswa untuk belajar tetap tinggi. Selain itu, berdasarkan observasi yang dilakukan di Fakultas Kedokteran Hewan, diperoleh kesimpulan bahwa fasilitas untuk pembelajaran e-learning di Fakultas Kedokteran Hewan sudah cukup memadai. Fasilitas yang ada berupa fasilitas hotspot, LCD di ruang kelas dan juga setiap mahasiswa memiliki smartphone untuk bisa mengakses internet. Namun, fasilitas yang ada tersebut belum bisa dimanfaatkan secara maksimal. Mahasiswa belum bisa menggunakan Google 
Classroom. Oleh karena itu, perlu dilaksanakan kegiatan pengabdian mengenai "Optimalisasi Penggunaan Google Classroom Sebagai Media E-learning bagi Mahasiswa Kedokteran Hewan Universitas Nusa Cendana".

\section{B. Masalah}

Masalah dalam pengabdian kepada masyarakat yang dilaksanakan pada mahasiswa kedokteran hewan adalah bagaimana potensi pembelajaran e-learning dan optimalisasi penggunaan google classroom sebagai media $e$-learning bagi mahasiswa kedokteran hewan Universitas Nusa Cendana.

\section{Metode Pelaksanaan}

Berdasarkan permasalahan hasil observasi di Fakultas Kedokteran Hewan, maka solusi yang ditawarkan adalah memberikan pelatihan bagaimana mengakses dan menggunakan media pembelajaran online Google Classroom kepada mahasiswa Kedokteran Hewan Universitas Nusa Cendana, sehingga mahasiswa dapat belajar, menyimak, membaca dan mengirim tugas dari jarak jauh menggunakan Google Classroom.

Pelaksanaan kegiatan pengabdian diselenggarakan di Fakultas Kedokteran Hewan meliputi persiapan, pelaksanaan pengabdian dan evaluasi. Kegiatan tersebut dapat dilihat pada tabel berikut ini:

Tabel 1. Kegiatan Optimalisasi Penggunaan Google Classroom Sebagai Media $e$ Learning Bagi Mahasiswa Kedokteran Hewan Universitas Nusa Cendana

\begin{tabular}{|c|c|c|}
\hline No. & Tahapan & Kegiatan \\
\hline 1 & Persiapan & $\begin{array}{l}\text { - Observasi di lapangan } \\
\text { - Merumuskan permasalahan-permasalahan yang } \\
\text { dihadapi oleh mahasiswa dalam mengoptimalkan } \\
\text { potensi pembelajaran online melalui media Google } \\
\text { Classroom } \\
\text { - Menyiapkan materi pelatihan, alat-alat dan bahan- } \\
\text { bahan yang diperlukan untuk kegiatan pelatihan }\end{array}$ \\
\hline 2 & Pelaksanaan & $\begin{array}{l}\text { Penyampaian materi e-learning dan cara mengakses } \\
\text { dan menggunakaan Google Classroom, serta } \\
\text { mendemontrasikan penggunaan Mendemonstrasikan } \\
\text { penggunaan Google Classroom sebagai media } \\
\text { pembelajaran yang telah dibuat dari hasil pelatihan. }\end{array}$ \\
\hline 3 & Evaluasi & $\begin{array}{l}\text { Evaluasi hasil kerja untuk mengetahui kendala selama } \\
\text { pelatihan }\end{array}$ \\
\hline
\end{tabular}




\section{Pembahasan}

\section{Persiapan}

Tahap kegiatan yang pertama dalam pengabdian ini adalah tahap persiapan (Tabel 1). Tahapan persiapan dapat berjalan sesuai dengan rencana yang telah disusun sebelumnya. Tindakan dalam tahapan persiapan adalah berupa implementasi program sebagai berikut. Tahap persiapan dilakukan untuk menggali masalah yang berkaitan dengan potensi pembelajaran e-learning. Khusus penggunaan media online Google Classroom. Dari hasil observasi diperoleh data bahwa fasilitas untuk pembelajaran e-learning di Fakultas Kedokteran Hewan sudah cukup memadai. Fasilitas yang ada berupa fasilitas hotspot, LCD di ruang kelas dan juga setiap mahasiswa memiliki smartphone untuk bisa mengakses internet. Namun, fasilitas yang ada tersebut belum bisa dimanfaatkan secara maksimal dikarenakan mahasiswa di Fakuktas kedokteran hewan belum memiliki softskill mumpuni dalam menggunakan e-learning, khusus nya Google Classroom. Oleh karena itu, kegiatan pelatihan penggunaan Google Classroom ini sangat penting dan akurat untuk untuk mahasiswa di Fakultas kedokteran agar pembelajaran lebih optimal sehingga visi dan misi Fakultas Kedokteran Hewan khusus nya terkait bidang pengajaran dapat tercapai dengan baik.

\section{Pelaksanaan}

Tahap kedua dalam kegiatan pengabdian ini adalah tahap pelaksanaan. Pada tahap ini dilakukan penyampaian materi e-learning dan pelatihan cara mengakses dan menggunakaan Google Classroom (Gambar 1). Tujuan kegiatan penyampaian materi e-learning adalah untuk membekali pengetahuan dan motivasi kepada mahasiswa betapa pentingnya pembelajaran online dalam menghadapi era revolusi industri 4.0. Sedangkan tujuan kegiatan pelatihan dan cara mengakses dan menggunakaan Google Classroom adalah untuk meningkatkan pengetahuan dan keterampilan para mahasiswa dalam menggunakan Google Classroom sebagai media pembelajaran online (Gambar 1). Selain itu, mahasiswa juga dapat lebih memahami penggunaan media Google Classroom karena pada kegiatan pelaksanaan ini dilakukan demontrasi penggunaan Google Classroom sebagai media pembelajaran yang telah dibuat dari hasil pelatihan. 


\section{Evaluasi}

Tahap ketiga dalam kegiatan pengabdian ini adalah tahap evaluasi. Pada tahap ini dilakukan Evaluasi untuk mengetahui kendala selama pelatihan. Kegiatan pengabdian yang dilaksanakan bagi mahasiswa di Fakultas Kedokteran Hewan Universitas Nusa Cendana telah berlangsung dengan baik. Hal ini terlihat dari sambutan positif dan antusiasme dari mahasiswa untuk mengikuti pelatihan dengan baik.
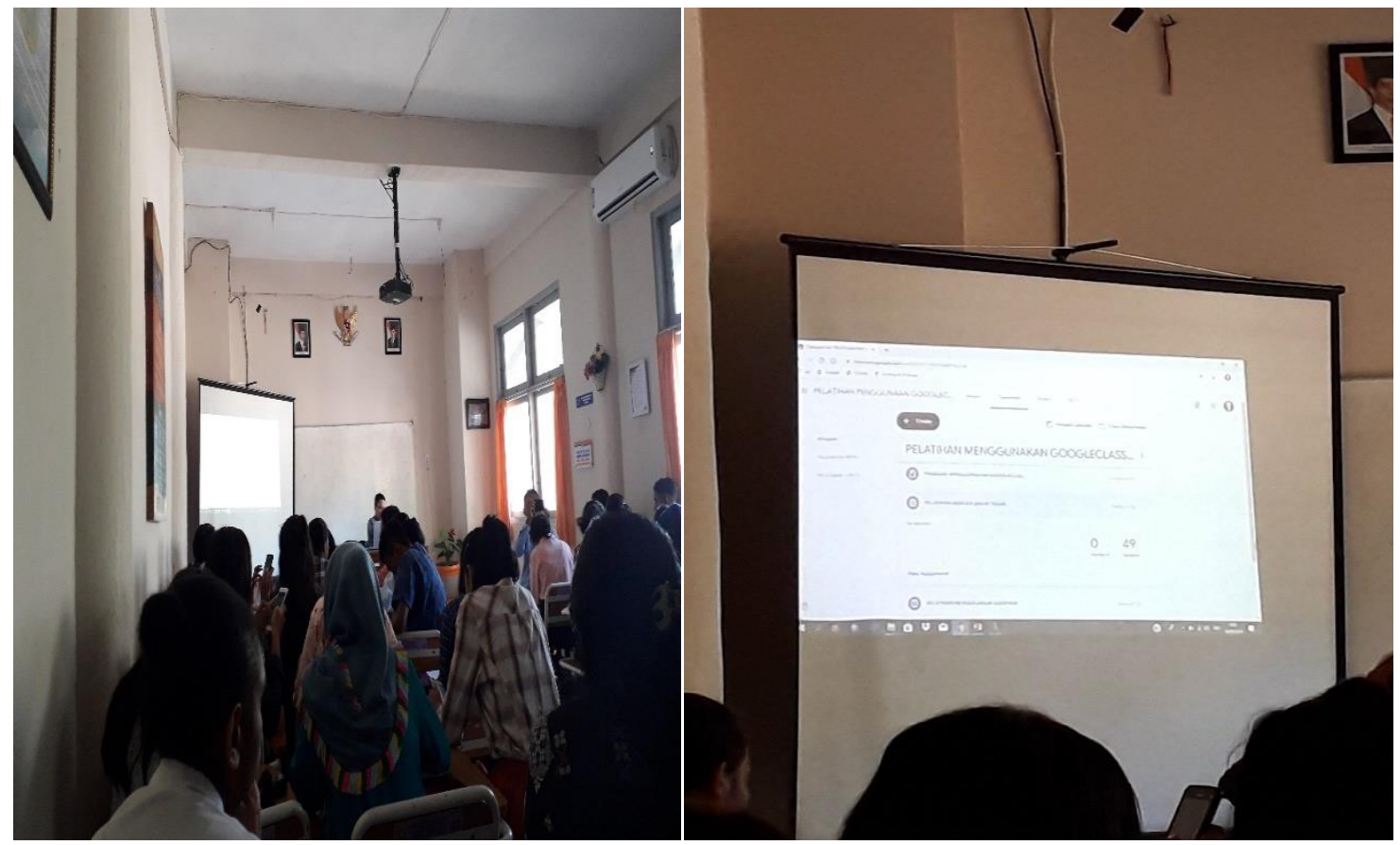

Gambar 1. Pelatihan penggunaan Google Classroom

\section{E. Kesimpulan}

Berdasarkan pelaksanaan kegiatan pengabdian masyarakat yang telah dilakukan, hasil yang dicapai bahwa bertambahnya pengetahuan mahasiswa Kedokteran Hewan di Universitas Nusa Cendana tentang pembelajaran e-learning dan terampil dalam menggunakan Google Classroom sebagai media pembelajaran online yang interaktif dan menyenangkan dalam proses kegiatan belajar mengajar dan adanya produk e-learning yaitu Google Classroom sebagai media pembelajaran online yang mudah digunakan. 


\section{DAFTAR PUSTAKA}

Al-adwan A., dan Smedly J. (2012). Implementing E-learning in the Jordanian Higher Education System: Factors Affecting Impact. International Journal of Education and Development using Information and Communication Technology (IJEDICT), 8(1): 121-135.

Algahtani A.F. (2011). Evaluating the Effectiveness of the E-learning Experience in Some Universities in Saudi Arabia from Male Students' Perceptions. Durham theses. Durham University.

Hakim, AB. (2016). Efektifitas Penggunaan E-learning Moodle, Google Classroom Dan Edmodo. I-statement: information system and technology management, 2(1): 2442-8337.

Jethro OO., Grace AM., Thomas AK. (2012). E-learning and Its Effects on Teaching and Learning in a Global Age. International Journal of Academic Research in Business and Social Sciences, 2(1).

Soni, Hafid A., Hayami R., Fatma Y., Wenando FA., Amien JA., et al. (2018). Optimalisasi Pemanfaatan Google Classroom Sebagai Media Pembelajaran di SMK Negeri 1 Bangkinang. Jurnal Pengabdian Untuk Mu Negeri 2(1):17-20. 